\title{
Persepsi Kepala Desa tentang Kompetensi Pendamping Desa dalam Memfasilitasi Pembangunan Desa
}

\section{Village Head's Perception about Village Facilitator Competence in Facilitating Village Development}

\author{
Zahrial Syah Alam ${ }^{1}$, Aida Vitayala S. Hubeis ${ }^{2}$, Ninuk Purnaningsih ${ }^{3}$ \\ 1,2,3 Departement of Communication Science and Community Development, Faculty of \\ Human Ecology, IPB University, Dramaga, Bogor, West Java, 16680 \\ e-mail: ${ }^{1}$ zahrial.s.a@gmail.com
}

\begin{abstract}
ABSTRAK
Kementerian Desa mengalokasikan dana khusus desa untuk pembangunan desa, yang difasilitasi oleh pendamping desa dengan bersinergi bersama kepala desa. Pendamping desa dituntut memiliki berbagai kompetensi dasar sesuai dengan peraturan kementerian desa, sehingga menjadi tolak ukur keberhasilan kegiatan pendampingan. Tulisan ini bertujuan untuk menganalisis pengaruh karakteristik kepala desa, interaksi kepala desa dengan pendamping desa, dan pengetahuan kepala desa tentang kompetensi pendamping desa terhadap persepsi kepala desa tentang kompetensi pendamping desa di Kabupaten Nagan Raya. Hasil penelitian menunjukkan masa kerja kepala desa akan mempengaruhi persepsinya terhadap kompetensi pendamping desa, hal ini disebabkan tingginya peluang interaksi antar kepala desa dengan pendamping desa, maka persepsi kepala desa tentang kompetensi pendamping desa semakin positif.
\end{abstract}

Kata kunci-kepala desa, kompetensi, pendamping desa

\section{ABSTRACT}

The Ministry of Villages allocates special village funds for village development, which is facilitated by village facilitators by working together with the village head. Village facilitators are required to have a variety of basic competencies in accordance with the regulations of the village ministry, so that it becomes a benchmark for the success of the assistance activities. This paper aims to analyzes the influence of the characteristics of the village head, the interaction of the village head with the village assistant, and the village head's knowledge of the competency of the village assistant on the village head's perception of the competency of the village assistant in Nagan Raya districs. The results showed that the village head's working period would affect his perception of the competency of village facilitators, this was due to the high chance of interaction between the village head and the village facilitator, so the village head's perception of the competency of village facilitators was more positive.

Keywords - competence, village companion, village head 


\section{PENDAHULUAN}

Undang-Undang Desa telah menempatkan desa sebagai ujung tombak pembangunan dan peningkatan kesejahteraan masyarakat. Desa diberikan kewenangan dan sumber dana yang memadai agar dapat mengelola potensi yang dimiliki guna meningkatkan ekonomi dan kesejahtaraan masyarakat. Setiap tahun pemerintah pusat telah menganggarkan dana desa yang cukup besar untuk diberikan kepada desa. Data yang diperoleh dari Kemenkeu (Kementerian Keuangan) tercatat bahwa pada tahun 2015, dana desa dianggarkan sebesar Rp20,7 triliun, dengan rata-rata setiap desa mendapatkan alokasi sebesar Rp280 juta. Pada tahun 2016, dana desa meningkat menjadi Rp46,98 triliun dengan rata-rata setiap desa sebesar Rp628 juta dan di tahun 2017 kembali meningkat menjadi Rp 60 triliun dengan rata-rata setiap desa sebesar Rp800 juta (Kemenkeu 2017).

Pemerintah berusaha untuk memaksimalkan pengelolaan dana desa dengan membentuk para pendamping desa, sebagai perpanjangan tangan pemerintah. Tugas pokok dari pendamping desa ialah memfasilitasi dan mendampingi masyarakat dalam penyelenggaraan pemerintahan desa, pelaksanaan pembangunan desa, pembinaan kemasyarakatan desa dan pemberdayaan masyarakat desa. Fasilitasi dilakukan dengan cara-cara yang kreatif dengan berpedoman kepada Undang-Undang Nomor 6 Tahun 2014 tentang desa beserta seluruh aturan pelaksanaannya. Pendamping desa bukan pengelola proyek pembangunan di desa, namun difokuskan pada upaya memberdayakan masyarakat desa melalui proses pembelajaran sosial.
Pendamping desa bergerak memfasilitasi pembangunan dan pemberdayaan masyarakat desa dengan berbekal keahlian, kreativitas, dan kemampuan diri dalam membaca kondisi politik, sosial, ekonomi dan budaya yang ada di setiap desa. Hal tersebut juga menjadi landasan utama mewujudkan tenaga pendamping profesional, yang nantinya dapat mengarah pada proses kaderisasi masyarakat desa. Menurut Pasal 2 huruf (b) Peraturan Menteri Desa Pembangunan Daerah Tertinggal, dan Transmigrasi Nomor 3 Tahun 2015 tentang Pendampingan Desa, pendamping desa seharusnya bekerjasama dengan perangkat desa untuk meningkatkan prakarsa, kesadaran, dan partisipasi masyarakat desa dalam pembangunan desa yang partisipatif (Kemendes 2015).

Berbagai permasalahan yang terjadi terkait program Dana Desa yang difasilitasi Pendamping Desa seperti penelitian Hadi et al. (2017) mengatakan masih terdapat kesenjangan yakni tugas yang dilakukan pendamping desa dan perangkat desa belum sesuai tupoksi masing-masing akibat dari belum siapnya perangkat desa melaksanakan tugas sebagai pengelola keuangan desa sehingga tugas tersebut dilaksanakan oleh pendamping desa. Hidayat (2016) mengatakan bahwa pendampingan desa mengalami berbagai masalah seperti rekrutmen, kualitas dan kompetensi tenaga pendamping, hingga ketidakjelasan konsep pendampingan desa. Selanjutnya Susanti (2017) mengatakan bahwa pemberdayaan masyarakat desa dilaksanakan antara lain dengan pendampingan desa, yang menunjukan pentingnya pendamping desa dalam menyelenggarakan pemerintahan desa. Faktanya bahwa keberadaan pelaksanaan pendamping 
desa belum maksimal dan belum sesuai dengan Peraturan Menteri Desa Pembangunan Daerah Tertinggal Dan Transmigrasi Nomor 3 Tahun 2015 tentang Pendampingan Desa.

Pendamping desa sebagai penggerak dan pelaku utama kegiatan pembangunan desa dituntut untuk dapat meningkatkan kompetensi yang nantinya akan dinilai oleh kepala desa serta masyarakat desa itu sendiri. Kepala desa yang terlibat dalam setiap kegiatan pembangunan desa juga dituntut untuk mengetahui tugasnya sendiri dan tugas para pendamping desa, sehingga mereka mampu menilai sejauhmana keberhasilan pendamping desa dalam melaksanakan standar kompetensi sebagai pendamping desa. Salah satu tugas pokok pendamping desa yang terdapat pada Undang-Undang Desa 2015 adalah memfasilitasi desa melaksanakan kegiatan-kegiatan pembangunan desa. Pembangunan desa tersebut merupakan jenis kegiatan prioritas dari dana desa, yaitu pengelolaan pelayanan sosial dasar, pengembangan usaha ekonomi desa, pendayagunaan sumber daya alam dan teknologi tepat guna, pembangunan sarana prasarana desa, dan pemberdayaan masyarakat desa. Sebagaimana yang dikatakan oleh Aziz (2016) bahwa tujuan akhir dari penggunaan dana desa adalah untuk peningkatan kesejahteraan masyarakat desa melalui pemberdayaan masyarakat desa dan kemasyarakatan. Ini sebagai bentuk umpan balik penggunaan dana desa dengan harapan dapat menciptakan pemerintahan dan masyarakat desa yang otonom dan mandiri untuk turut ambil bagian dalam pembangunan nasional. Kabupaten Nagan Raya memiliki sepuluh kecamatan dengan jumlah pendamping desa sebanyak 56 orang yang tersebar di 224 desa. Selama tiga tahun terakhir para pendamping desa telah melakukan kegiatan pembangunan sarana dan prasarana, seperti jalan desa, jembatan, drainase, penahan tanah, dan lain sebagainya. Sebanyak 16 kegiatan pembangunan yang telah dilakukan, sejauh ini telah menghabiskan dana desa sebanyak 70 milyar. Sebagian besar dana desa telah dimanfaatkan untuk pembangunan dan pemberdayaan masyarakat desa. Namun belum semua kegiatan seperti pembangunan pasar desa, Polindes, Bumdes, dan Posyandu dilakukan secara merata di seluruh desa. Hal tersebut menjadi penilaian bagi kepala desa terhadap kompetensi pendamping desa.

Interaksi kepala desa dengan pendamping desa juga memberi peluang kepada kepala desa untuk menambah pengetahuan tentang tugas dan kompetensi pendamping desa. Semakin sering kepala desa melakukan kontak dengan pendamping desa, diharapkan semakin banyak pengetahuan yang diperoleh. Sebagaimana penelitian Parwati et al (2017) dan Saputra et al (2018) mengatakan bahwa kompetensi pendamping desa memiliki pengaruh yang signifikan terhadap keberhasilan pengelolaan dana desa. 


\section{METODE PENELITIAN}

Penelitian dilakukan di Kabupaten Nagan Raya, Provinsi Aceh. Penelitian ini sendiri terfokus ke pada 2 kecamatan dari 10 kecamatan yang di tempati oleh pendamping desa. Kecamatan tersebut adalah Senagan Timur dan Darul Makmur. Penentuan daerah penelitian didasarkan atas pertimbangan bahwa kecamatan-kecamatan tersebut mendapatkan program pendamping desa. Penentuan lokasi penelitian dilakukan secara purposive (sengaja).

Populasi penelitian adalah 224 kepala desa yang berasal dari sepuluh kecamatan di Kabupaten Nagan Raya yaitu Kecamatan Beutong, Beutong Ateuh Banggalang, Darul Makmur, Kuala, Kuala Pesisir, Seunagan, Senagan Timur, Suka Makmur, Tadu Raya, dan Tripa Makmur. Pada penelitian hanya dilakukan pada dua kecamatan yaitu Kecamatan Darul Makmur dan Seunagan Timur. Jumlah desa dari dua kecamatan itu adalah 74, dan akan disensus. Pemilihan dua kecamatan ini bertujuan untuk melihat bagaimana perbandingan antara kecamatan yang sudah maju (Darul Makmur) dan kecamatan belum maju (Seunagan Timur).

Penelitian dirancang berdasarkan metode deskriptif eksplanatori, dengan pendekatan penelitian kuantitatif yang didukung dengan data-data kualitatif. deskriptif eksplanatori dimaksudkan untuk menjelaskan dan menguji pengaruh peubah-peubah yang diamati (Riduwan 2012). Peubah yang diamati meliputi dua peubah bebas dan satu peubah terikat (tidak bebas). Kedua peubah bebas tersebut terdiri atas: $\left(\mathrm{X}_{1}\right)$ Karakteristik kepala desa, $\left(\mathrm{X}_{2}\right)$ Interaksi kepala desa dengan pendamping desa, dan $\left(\mathrm{X}_{3}\right)$ pengetahuan kepala desa tetang pendamping desa. Selanjutnya, untuk peubah terikat (tidak bebas) yaitu (Y) Persepsi kepala desa tentang kompetensi pendamping desa.

Data hasil penelitian dianalisis menggunakan statistik deskriptif dan inferensial. Analisis statistik deskriptif dilakukan untuk memberikan gambaran terhadap peubah bebas dan peubah terikat menggunakan teknik peringkasan data seperti pengkategorian (skoring) dan rataan kemudian disajikan menggunakan tabel frekuensi. Data yang diperoleh dari kuesioner dikelompokkan menurut peubah yang telah ditentukan dengan menggunakan skoring dan pengkategorian. Pengolahan data menggunakan program Microsoft Excel dan SPSS (Statistical Product and Service Solution) versi 23.

Analisis dilakukan untuk mengetahui arah pengaruh antara peubah bebas dan peubah terikat apakah positif atau negatif dan untuk memprediksi nilai dari peubah terikat apabila nilai peubah bebas mengalami kenaikan atau penurunan. Data yang digunakan biasanya berskala interval atau rasio. Rumus regresi linear berganda adalah sebagai berikut:

$$
Y=\rho y x 1 X 1+\rho y x 2 X 2+\ldots+\rho y x k X k+\varepsilon
$$

Di mana:

$\begin{array}{ll}\mathrm{Y} & =\text { variabel terikat (endogen) } \\ \mathrm{X} 1, \mathrm{X} 2, \ldots \mathrm{Xk}= & \text { variabel bebas (eksogen) } \\ \rho & \text { koefisien jalur antara } \\ & \text { variabel penyebab dan } \\ & \text { variabel akibat } \\ = & \text { variabel residu (error) }\end{array}$




\section{HASIL DAN PEMBAHASAN}

\section{Program Dana Desa Kabupaten Nagan Raya}

Dana desa merupakan bantuan keuangan dari APBD provinsi, kabupaten, atau kota, hibah dan sumbangan pihak ketiga, dan lain-lain pendapatan yang sah. Ini bertujuan supaya pemerintah desa dapat memberikan pelayanan prima dengan memberdayakan masyarakat untuk berpartisipasi aktif dalam program kegiatan pembangunan baik fisik maupun non fisik sehingga tercapai pembangunan dan peningkatan kesejahteraan masyarakat desa. Kebijakan penggunaan dana desa bertujuan untuk mendorong pertumbuhan ekonomi dalam menjaga tingkat konsumsi rumah tangga, tingkat pendapatan, dan tingkat inflasi yang stabil. Selain itu juga untuk meningkatkan konektivitas melalui pembangunan infrastruktur dengan mendorong stabilitas harga dan distribusi yang lebih merata (Aziz, 2016).

Pada pasal 100 PP No. 43/2014 tentang keuangan desa, bahwasanya penggunaan dana desa dibagi menjadi $30 \%$ untuk operasional penyelenggaraan pemerintahan desa dan $70 \%$ untuk kemasyarakatan, pemberdayaan, dan pembangunan. Kemudian PP No. 60/2014 dan PP No.22/2015 mengatur penggunaan dana desa berdasarkan 4 (empat) bidang yakni penyelenggaraan pemerintahan desa, pembangunan, pemberdayaan masyarakat, dan kemasyarakatan.
Penggunaan dana desa di Kabupaten Nagan Raya hingga tahun 2017 mencapai 70 milyar, yang direalisasikan ke 10 kecamatan. Dana tersebut digunakan untuk pembangunan sarana dan prasarana di setiap kecamatan, seperti jalan desa, jembatan, MCK, PAUD, Posyandu, Bumdes, dan sebagainya.

\section{Pengaruh Karakteristik Kepala Desa, Interaksi Kepala Desa dengan Pendamping Desa, dan Pengetahuan Kepala Desa tentang Kompetensi Pendamping Desa terhadap Persepsi Kepala Desa tentang Kompetensi Pendamping Desa}

Analisis faktor yang berpengaruh terhadap persepsi kepala desa tentang kompetensi pendamping desa dilakukan menggunakan analisis regresi linear berganda menggunakan SPSS. Hasil analisis menunjukkan bahwa faktor yang berpengaruh nyata terhadap persepsi kepala desa tentang kompetensi pendamping desa adalah masa kerja dan pengetahuan kepala desa tentang pendamping desa, sedangkan umur, pendidikan formal, dan interaksi kepala desa dengan pendamping desa tidak berpengaruh nyata.

Pada Tabel 1, hasil penelitian menunjukkan bahwa pengetahuan kepala desa tentang pendamping desa berpengaruh negatif terhadap pengembangan usaha ekonomi desa dengan nilai koefisien $\beta$ sebesar -0,207, hal ini disebabkan ketika masa PNPM (Program Nasional Pemberdayaan Masyarakat) banyak masyarakat yang tidak mengembalikan dana kredit sesuai dengan perjanjian yang sudah disepakati, sehingga usaha kredit mikro desa dialihkan ke usaha ekonomi kreatif desa dan pengelolaan Bumdes. Pengembangan usaha kredit mikro desa tidak sampai ke tahap terbentuknya unit 
legal, namun hanya sampai ke tahap sosialisasi, karena pendamping desa tidak mempunyai ide dalam pengelolaan simpan pinjam usaha kredit mikro tersebut.

Tabel 1 Nilai koefisien regresi, thitung dan signifikasi variabel independen terhadap pengembangan usaha ekonomi desa $\left(\mathrm{Y}_{2}\right)$

\begin{tabular}{llccc}
\hline No & \multicolumn{1}{c}{ Variabel } & $\begin{array}{c}\text { Koefisien } \\
\text { Regresi }\end{array}$ & T hitung & Sig. \\
\hline 1 & R-square & 0.089 & & \\
2 & Umur $\left(\mathrm{X}_{11}\right)$ & -0.047 & -0.338 & 0.737 \\
3 & Pendidikan formal $\left(\mathrm{X}_{12}\right)$ & -0.035 & -0.225 & 0.823 \\
4 & Masa kerja $\left(\mathrm{X}_{13}\right)$ & 0.199 & 1.566 & 0.122 \\
5 & Interaksi kepala desa dengan pendamping desa & -0.068 & -0.665 & 0.508 \\
& (X) & & & \\
6 & Pengetahuan kepala desa tentang pendamping & $\mathbf{- 0 . 2 0 7}$ & $\mathbf{- 1 . 7 9 1}$ & $\mathbf{0 . 0 7 8 *}$ \\
& desa $\left(\mathrm{X}_{3}\right)$ & & & \\
\hline
\end{tabular}

Keterangan: *) Signifikan pada 0.1

Pendamping desa diharapkan dapat menerima berbagai masukan dan ide sejalan dengan penelitian Suswanto dan Suswanto et al. (2018) mengatakan bahwa pendamping desa dalam menjalankan peran dan fungsinya, dapat melakukan proses studi atau kajian secara berkesinambungan dengan sesama pendamping sebagai tim kerja agar lebih membantu dalam mengidentifikasi dan menganalisis permasalahan, potensi sumber daya dan prospek pembangunan di desa.

Pada proses pengembangan ekonomi desa, pendamping desa dalam menjalankan programnya terkendala dengan ide serta program yang kreatif.
Hanya sebagian pendamping desa yang sudah berinisiatif menerapkan berbagai program pengembangan usaha ekonomi desa jangka panjang seperti pengadaan bibit sapi, dimana sapi tersebut dikembangbiakan sampai melahirkan dan diberi tanda untuk diserahkan kepada masyarakat desa sebagai modal. Selanjutnya ketika ada acara perayaan keagamaan serta adat istiadat, maka sapi tersebut bisa dijual dan hasilnya diberikan kepada masyarakat dan Bumdes. selanjutnya pengadaan perkebunan sawit yang proses pengelolaannya juga sama seperti bibit sapi, di mana masyarakat diikutsertakan dalam proses perawatan, pemupukan, dan panen.

Tabel 2 Nilai koefisien regresi, thitung dan signifikasi variabel independen terhadap pembangunan sarana dan prasarana desa $\left(\mathrm{Y}_{3}\right)$

\begin{tabular}{|c|c|c|c|c|}
\hline No & Variabel & $\begin{array}{c}\text { Koefisien } \\
\text { Regresi }\end{array}$ & $\mathrm{T}$ hitung & Sig. \\
\hline 1 & R-square & 0.091 & & \\
\hline 2 & $\operatorname{Umur}\left(\mathrm{X}_{11}\right)$ & 0.180 & 0.808 & 0.422 \\
\hline 3 & Pendidikan formal $\left(\mathrm{X}_{12}\right)$ & 0.079 & 0.312 & 0.759 \\
\hline 4 & Masa kerja $\left(\mathrm{X}_{13}\right)$ & 0.199 & 1.630 & 0.108* \\
\hline 5 & $\begin{array}{l}\text { Interaksi kepala desa dengan pendamping desa } \\
\left(\mathrm{X}_{2}\right)\end{array}$ & -0.159 & -0.960 & 0.341 \\
\hline 6 & $\begin{array}{l}\text { Pengetahuan kepala desa tentang pendamping } \\
\text { desa }\left(\mathrm{X}_{3}\right)\end{array}$ & 0.328 & -1.759 & $0.083 *$ \\
\hline
\end{tabular}

Keterangan: *) Signifikan pada 0.1 
Hasil penelitian menunjukkan bahwa masa kerja kepala desa tentang pendamping desa berpengaruh positif terhadap pembangunan sarana dan prasarana desa dengan nilai koefisien $\beta$ sebesar 0,199. Hal tersebut menunjukkan bahwa masa kerja kepala desa memberikan persepsi yang baik, karena dalam proses berjalannya program pembangunan sarana dan prasarana desa kepala desa ikut melihat dan memantau proses yang dijalankan oleh pendamping desa. Masa kerja kepala desa yang mencapai rata-rata lima tahun membuat mereka mengerti terkait program pembangunan desa. Tahapantahapan yang mereka lalui bersama para pendamping desa yang menjadi fasilitator seperti menghubungi pihak terkait, persiapan pengelolaan, menyiapkan lokasi serta bahan kebutuhan, dan melaksanakan pembangunan. Sebagaimana penelitian Aziz (2016) mengatakan bahwa penggunaan dana desa bertujuan untuk mendorong pertumbuhan ekonomi dalam menjaga tingkat konsumsi rumah tangga, tingkat pendapatan, dan tingkat inflasi yang stabil. Selain itu juga untuk meningkatkan konektivitas melalui pembangunan infrastruktur dengan mendorong stabilitas harga dan distribusi yang lebih merata.

Pengetahuan kepala desa tentang pendamping desa juga berpengaruh positif terhadap persepsi kepala desa tentang kompetensi pendamping desa dalam kegiatan pembangunan sarana dan prasarana desa di Kabupaten Nagan Raya dengan nilai koefisien $\beta$ sebesar 0,328. Kepala desa menilai bahwa pendamping desa telah berhasil melakukan setiap kegiatan pembangunan sarana dan prasarana desa, serta ikut terlibat langsung dalam setiap kegitan yang dilakukan. Kepala desa ikut menemani para kader desa yang diberikan pelatihan dan bimbingan teknis oleh pendamping desa. Pelatihan dan bimbingan teknis yang diberikan berupa pembuatan desain, RAB (Rencana Anggaran Biaya), pengelolaan, serta pemeliharaan sarana dan prasarana. Pendamping desa juga turut mengundang tim ahli untuk membantu mereka memberikan pelatihan kepada para kader desa. Tujuan pendamping desa mengundang tim ahli adalah untuk menambah berbagai referensi ilmu dan menutup kekurangan yang belum mereka kuasai. Sejalan dengan penelitian Prabawa (2015) yang mengatakan bahwa pendamping desa dalam meberikan fasilitias berupa proses kerjasama dengan pihak ketiga dan atau dengan desa lain merupakan peran terpenting sebagai upaya mewujudkan kemandirian desa. Secara normatif kerjasama dengan desa lain atau dengan pihak ketiga untuk mengembangkan dan mempangun desa.

Tabel 4 Nilai koefisien regresi, $\mathrm{t}$ hitung dan signifikasi variabel independen terhadap persepsi kepala desa tentang kompetensi pendamping desa $\left(\mathrm{Y}_{\text {total }}\right)$

\begin{tabular}{clccc}
\hline No & Variabel & $\begin{array}{c}\text { Koefisien } \\
\text { Regresi }\end{array}$ & $\begin{array}{c}\mathrm{T} \\
\text { hitung }\end{array}$ & Sig. \\
\hline 1 & R-square & 0.054 & & \\
2 & Umur $\left(\mathrm{X}_{11}\right)$ & 0.000 & -0.003 & 0.998 \\
3 & Pendidikan formal $\left(\mathrm{X}_{12}\right)$ & 0.010 & 0.444 & 0.659 \\
4 & Masa kerja $\left(\mathrm{X}_{13}\right)$ & $\mathbf{0 . 0 2 1}$ & $\mathbf{1 . 8 3 7}$ & $\mathbf{0 . 0 7 1 *}$ \\
\hline
\end{tabular}




\begin{tabular}{lllllll}
\hline 5 & \multicolumn{2}{l}{$\begin{array}{l}\text { Interaksi kepala desa dengan pendamping } \\
\text { desa }\left(\mathrm{X}_{2}\right)\end{array}$} & -0.007 & -0.475 & 0.639 \\
6 & $\begin{array}{l}\text { Pengetahuan kepala } \\
\text { pendamping desa }\left(\mathrm{X}_{3}\right)\end{array}$ & desa & tentang & -0.003 & -0.197 & 0.844 \\
\hline
\end{tabular}

Keterangan: *) Signifikan pada 0.1

Hasil penelitian menunjukkan bahwa masa kerja berpengaruh terhadap persepsi kepala desa tentang kompetensi pendamping desa dengan nilai koefisien $\beta$ sebesar 0,021 . Hal ini menunjukkan bahwa lamanya masa kerja kepala desa memberikan peluang interaksi antara kepala desa dengan pendamping desa, sehingga kepala desa lebih mudah dalam menilai setiap kompetensi yang telah dilaksanakan oleh pendamping desa, begitu pula sebaliknya.

Kepala desa mempunyai persepsi positif kepada pendamping desa karena mereka terbantu dengan adanya pendamping desa. Pendamping desa yang menjadi fasilitator untuk kepala desa dalam hal pengelolaan dana desa mempunyai peran yang besar. Kepala desa berharap kepada pendamping desa agar bisa maksimal membantu dalam hal pengelolaan dana desa. Sebagaimana yang diunkapkan oleh Sunarti (2016) adanya pendamping desa diharapkan dapat tercipta pembangunan yang partisipatif dari pemerintah desa dan masyarakat, pembangunan fasilitas dan meningkatkan perekonomian masyarakat desa menjadi bagian dari pembangunan nasional, sebagai langkah kongkrit pemerintah pusat untuk meningkatkan kualitas dan kuantitas sumber daya manusia pedesaan.

Dana desa yang diberikan setiap tahun oleh pemerintah melalui Kementerian Keuangan dengan program yang disusun oleh Kementerian Desa Pembangunan Daerah Tertinggal dan Transmigrasi, membuat kepala desa membutuhkan pendamping desa untuk menjalankan program serta tugas yang harus dijalankan sesuai dengan UU Kemendesa. Sejalan yang diungkapkan oleh Ghozali (2015) pendampingan desa mampu memfasilitasi masyarakat supaya mampu secara mandiri melaksanakan pembaharuan dan pembangunan desa, pendamping desa juga bertugas untuk menemukan, mengembangkan potensi dan kapasitas, serta mendampingi para penggerak pembaharuan untuk melaksanakan pemberdayaan masyarakat sebagai proses transformasi sosial yang dilaksanakan mayarakat desa sebagai agen pembaharuan. Kepala desa juga sangat membutuhkan pendamping desa karena program dan tugas yang harus dilakukan sesuai UU Kemendesa sebagian besarnya di luar dari kapasitas kepala desa. Hanya sebagian tugas kepala desa sesuai dengan UU pemerintah daerah yang sama dengan tugas pendamping desa yaitu menetapkan anggaran dan pendapatan belanja desa, meningkatkan perekonomian desa, mengembangkan sumber pendapatan desa, dan memanfaatkan teknologi tepat guna, selebihnya merupakan tugas baru bagi kepala desa.

Pandangan kepala desa terhadap pendamping desa selama adanya program dana desa beragam. Sebagian besar kepala desa menganggap program pembangunan desa di desa tempatnya bertugas sudah mencukupi, walaupun pembangunan tersebut dianggap belum terlalu penting digunakan untuk saat ini, menurutnya bangunan tersebut bisa berguna suatu saat nanti. Bagi kepala desa tersebut yang paling penting ada 
pembangunan yang dilakukan di desanya. Oleh karena itu peran masyarakat seperti tokoh pemuda, pemuka agama dan adat, dan kaderkader perubahan dibutuhkan untuk memberikan masukan kepada kepala desa yang nantinya akan didiskusikan kepada pendamping desa. Selanjutnya, ada pula kepala desa yang sudah menganalisa pembangunan apa saja yang seharusnya dilakukan di desa tempatnya bertugas. Keberagaman persepsi tersebut muncul berdasarkan pengalaman yang didapatkan oleh kepala desa dari sosialisasi program dana desa yang diadakan oleh pemerintah pusat maupun daerah, informasi yang mereka dapatkan melalui media massa, dan diskusi antara kepala desa.

\section{KESIMPULAN}

Secara umum masa kerja kepala desa akan mempengaruhi persepsinya terhadap kompetensi pendamping desa, hal ini disebabkan tingginya peluang interaksi antar kepala desa dengan pendamping desa, maka persepsi kepala desa tentang kompetensi pendamping desa semakin positif. Secara khusus pengetahuan kepala desa berpengaruh positif terhadap persepsi kepala desa tentang kompetensi pedamping desa dalam kegiatan pembangunan sarana dan prasarana desa, hal ini dikarenakan kepala desa merasa pendamping desa telah berhasil melaksanakan setiap kegiatan pembangunan sarana prasarana desa berdasarkan ketentuan UU Kemendesa. Selanjutnya pengetahuan kepala desa tentang pendamping desa berpengaruh negatif terhadap persepsi kepala desa tentang kompetensi pendamping desa dalam kegiatan pengembangan usaha ekonomi desa, hal ini disebabkan karena pendamping desa tidak mempunyai ide dalam pengelolaan simpan pinjam usaha kredit mikro.
Umur, pendidikan formal, dan interaksi kepala desa dengan pendamping desa tidak berpengaruh terhadap persepsi kepala desa tentang kompetensi pendamping desa, hal ini disebabkan karena kepala desa perlu mengetahui setiap tugas pendamping desa agar dapat menilai keberhasilan kompetensi pendamping desa.

\section{SARAN}

Diperlukannya perhatian dari berbagai pihak yang memiliki kapasitas dan kemampuan seperti kader perubahan, tokoh masyarakat, tokoh adat dan pemuka agama dalam mengembangkan berbagai kegiatan pembangunan desa seperti pengelolaan pelayanan sosial dasar, pengembangan usaha ekonomi desa, pembangunan sarana dan prasarana, dan pemberdayaan kepada masyarakat desa, agar pendamping desa bisa mendapatkan berbagai masukan khususnya pada program yang belum berhasil dilakukan. Adanya saran dan ide-ide untuk berbagai kegiatan pembangunan desa akan membantu kepala desa dan juga pendamping desa dalam menjalanankan berbagai program yang nantinya mudah diterima oleh masyarakat dan juga dalam pengelolaannya.

\section{DAFTAR PUSTAKA}

Aziz NLL. 2016. Otonomi Desa Dan Efektivitas Dana Desa. Jurnal Penelitian Politik. 2 (13)

Ghozali DA. 2015. Kader Desa: Penggerak Prakarsa Masyarakat Desa. Jakarta:Kementerian Desa, Pembangunan Daerah Tertinggal dan Transmigrasi RI

Hadi ER, Murdyastuti A, Puspitaningtyas Z. 2017. Pengaruh 
Evaluasi

Kebijakan

Pendampingan Pengelolaan

Keuangan Desa dan Kompensasi

Terhadap Kinerja Tenaga

Fasilitasi Pendamping Desa Di

Kabupaten Lumajang. Jurnal Dian Ilmu. 1 (17).

Hidayat TM. 2016. Pendamping Desa Kontekstual. Jurnal Analsis Kebijakan. 1 (2)

[Kemendes] Peraturan Undang Kementerian Desa Nomor 3 Tahun 2015 Tentang Desa [Internet]. [diunduh 15 Januari 2017]. Tersedia pada: http://jdih.kemendesa.go.id/katalo g/peraturan_menteri_desa_pemba ngunan_daerah_tertinggal_dan_t ransmigrasi_nomor_3_tahun_201 5

[Kemenkeu] Kementerian Keuangan 2017. Buku Saku Dana Desa [Internet]. [diunduh 2 Januari 17]. Tersedia pada: https://www.kemenkeu.go.id/medi a/6750/buku-saku-dana-desa.pdf_.

Parwati, Juni K, Purnamawati IGA, Prayudi MA. 2017. Pengaruh Kompetensi Pendamping Desa, Sistem Pengendalian Internal Pemerintah Desa, dan Komitmen Aparatur Desa Terhadap Keberhasilan Pengelolaan Dana Desa Di Kabupaten Buleleng. Jurnal Ilmiah Mahasiswa Akuntansi. 2 (8)

Prabawa A. 2015. Pengelolaan Alokasi Dana Desa dalam Pembangunan di Desa Loa Lepu Kecamatan Tenggarong Selatan Kabupaten Kutai Kertanegara. Jurnal Ilmu Pemerintahan.

Riduwan. 2012. Pengantar Statistika Sosial. Bandung (ID): Alfabeta.
Saputra, Kurniawan KA, Atmadja AT, Koswara MK. 2018. The Influence Of Village Conflict, Village Apparatus Ability, Village Facilitator Competency And Commitment Of Local Government On The Success Of Budget Management [Internet]. [diunduh 5 Maret 2020] Tersedia pada:

https://www.abacademies.org/ articles/the-influence-ofvillageconflict-villageapparatus-abilityvillagefacilitator-competency15282635-22-1-102.pdf

Sunarti V. 2016. Peranan Pendamping Desa dalam Membentuk Masyarakat Sadar Bencana sebagai salah Satu Mitigasi Bencana.[Prosiding]. Seminar Nasional Jurusan Pendidikan Luar Sekolah, Fakultas Ilmu Pendidikan. Universitas Negeri Padang.

Susanti MH. 2017. Peran Pendamping Desa dalam Mendorong Prakarsa dan Partisipasi Masyarakat Menuju Desa Mandiri di Desa Gonoharjo Kecamatan Limbangan Kabupaten Kendal. Jurnal Integralistik. 1(28)

Suswanto B, Sulistyoningsih ED. 2018. Sarjana Pendamping Desa Sebagai Community Development Dalam Pemberdayaan Masyarakat. [Prosiding] Seminar Nasional Pengembangan Sumber Daya Perdesaan dan Kearifan Lokal Berkelanjutan. Purwokerto. 